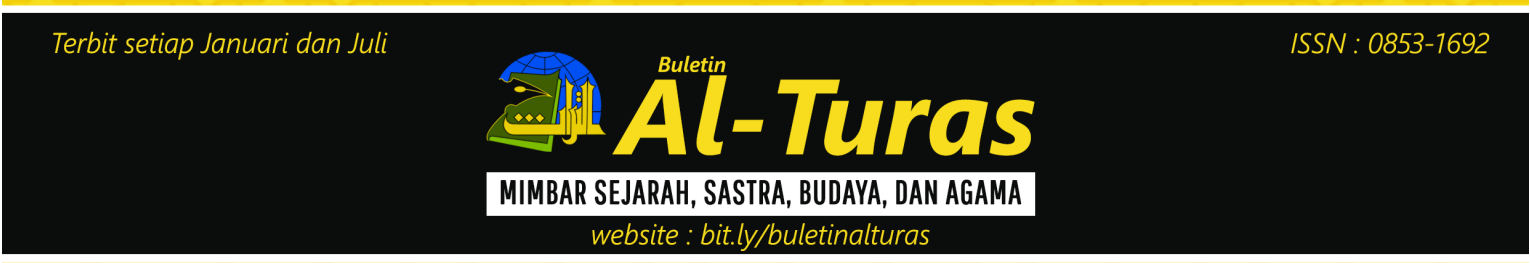

\title{
Perang dan Percintaan dalam Sajak-Sajak Clarence Michael James Dennis
}

\author{
Deny Gunawan Susandi ${ }^{1}$
}

\begin{abstract}
This research focuses on analyzing Clarence Michael James Dennis's character and works that illustrate the atmosphere of natural beauty and romance in Australia when during and after the war. In this paper also explained that the development of literary works in the UK affect the development of literary works in Australia. The works sampled in this study are the works of C.J Dennis made before World War 1, until after World War 1 was completed. The values of humanity, the atmosphere of war, and romance became the cirikhas of C. Dennis's poems. The study concludes that C. J Dennis is a world writer thanks to his synchronized work and is relevant to the issues that can be absorbed by the world community, as well as explaining how the first world war from the standpoint of the army world.
\end{abstract}

Keywords: Australian Poets; C.J Dennis; Modern Period; History of Literature

\section{Abstrak}

Penelitian ini berfokus pada analisis tokoh dan karya Clarence Michael James Dennis yang menggambarkan suasana keindahan alam dan percintaan di Australia ketika saat dan setelah perang. Pada paper ini juga dijelaskan bahwa perkembangan karya sastra di Inggris mempengaruhi perkembangan karya sastra di Australia. Karya-karya yang dijadikan sample pada penelitian ini adalah karya-karya C.J Dennis yang dibuat sebelum perang dunia 1, hingga setelah perang dunia 1 selesai. Nilai-nilai kemanusiaan, suasana perang, dan percintaan menjadi cirikhas dari sajak-sajak C.J Dennis. Penelitian ini menyimpulkan bahwa C.J Dennis merupakan sastrawan dunia berkat karya-karyanya yang sinkron dan relevan dengan isu yang dapat diserap oleh masyarakat dunia, serta menjelaskan tentang bagaimana perang dunia pertama dari sudut pandang dunia tentara.

Kata kunci: Australian Poets; C.J Dennis; Periode Modern; Sejarah Sastra

\footnotetext{
${ }^{1}$ Ilmu Susastra (Sastra), Dept. Susastra, Fakultas Ilmu Pengetahuan Budaya, Universitas Indonesia, Depok, Indonesia, email: deny.gunawan72@ui.ac.id
} 


\section{A. Pendahuluan}

Melakukan apresiasi terhadap sebuah karya satra, merupakan hal yang mencakup tentang penghargaan atau kesadaran akan ada nilai pada suatu karya. ${ }^{2}$ Apresiasi tersebut pada akhirnya akan bermuara pada bagaimana seseorang, atau kelompok, memahami sebuah karya sastra. Namun, tidak heran bila, Sapardi Djoko Damono mengungkapkan bila tidak sedikit anggota masyarakat yang memberikan apresiasi kepada sebuah karya, atau penulisnya, tanpa melewati proses pemahaman sebuah karya. Lalu, bagaimana cara agar seseorang, entah itu profesional atau pembaca biasa, dapat memahami sebuah karya sastra? Beberapa cara tentu memiliki hasilnya sendiri. Namun, yang paling mudah adalah menarik hubungan antara karya sastra, pembaca, dan sastrawannya itu sendiri (penulis). ${ }^{3}$

Karya sastra tak ubahnya sebuah seni yang dapat dinikmati. Dalam kuliahnya di Fakultas Ilmu Pengetahuan Budaya, Universitas Indonesia, Mina Elfira memberikan pemaparan mengenai fungsi karya sastra itu sendiri. Menurutnya karya sastra memiliki sifat Dulce et Utile, yaitu keindahan dan manfaat. Berbicara soal keindahan, tentu tidak terbantahkan lagi dan tidak memerlukan pemaparan panjang untuk menikmati keindahan karya sastra. Namun, yang paling menarik adalah bagaimana karya sastra dapat memberikan manfaatnya untuk masyarakat, atau untuk pembacanya.

Salah satu hal yang perlu diamati dari karya sastra, untuk mendapatkan manfaatnya, adalah dengan melihat

${ }^{3}$ Damono, 2. catatan-catatan sejarah dari sebuah karya. Dalam Pengantar Sejarah Sastra Indonesia Yudiono mengutip sebuah pengertian dari sejarah sastra yang diungkapkan oleh Luxemburg. ${ }^{4}$ Dalam kutipan tersebut, ia menerangkan bahwa sejarah sastra, bukan hanya merupakan sesuatu yang perlu diingat, melainkan sebuah kajian yang membahas pertumbuhan dan perkembangan sastra yang terdapat dalam suatu bangsa. Lebih dalam lagi, Yudiono memberikan contoh-contoh di mana sejarah sastra tidak hanya membahas tentang periodenya saja, namun juga aliran, jenis, pengarang, dan juga reaksi pembaca (resepsi). Sehingga, ketika hal-hal tersebut disatukan dalam sebuah pembahasan dan menjadi disiplin keilmuan, ilmu-ilmu lain, seperti filsafat dan sosial, akan turut membantu dan mencerahkan. ${ }^{5}$ Hal tersebut tentunya tidak terlepas dari bagaimana sastra dan masyarakat yang saling berhubungan satu dengan yang lain. Sehingga pengaruh yang "bersentuhan" langsung kepada karya sastra tersebut, memberikan efek kepada karya tersebut. Kecenderungan tematik atau isi karya yang, serta pengaruh lingkungan sosial dan masyarakat juga mempengaruhi ideologi pengarang dalam menghasilkan suatu karya sastra.

\section{B. Pembahasan}

\section{Sejarah Kesusastraan Inggris}

Berbicara tentang kesusastraan, tentu pandangan kita akan sampai pada bagaimana karya sastra berkembang di Eropa. Terlebih karya sastra berkembang dengan signifikan pada saat masa kejayaan romawi (Yunani) kuno.

${ }^{4}$ Yudiono, Pengantar Sejarah Sastra Indonesia., 26.

${ }^{5}$ Yudiono, 26. 
Pada saat itu, posisi karya sastra sejajar dengan kepercayaan masyarakat yang memuja dan menyembah dewa-dewa, yang saat ini kita kenal dalam mitologi. Sehingga tidak heran memang bila kebanyakan, atau bahkan seluruhnya, karya sastra di periode klasik (Classic Period) hingga era Renaissance memiliki kecenderungan cerita yang menceritakan dewa-dewa.

Setelahnya, era kesusastraan memasuki masa di mana genre surealism mulai ditinggalkan. Banyak penikmat karya sastra yang ingin menikmati sastra sebagai sebuah refleksi dari apa yang benar-benar terjadi di masyarakat. Sehingga pada saat masa "keemasan" sastra yang membahas tentang mitologi dewa-dewa selesai, muncul karya-karya sastra yang ditulis oleh penulis Eropa dengan genre realism, yakni pada saat memasuki Victorian Era dan seterusnya.

Dalam bukunya yang berjudul An Outline History of English Literature, Hudon mengatakan bahwa sejarah sastra Inggris merupakan catatan kronologis karya-karya sastra dalam bahasa Inggris beserta penulisnya. ${ }^{6}$ Hal ini menyimpulkan bahwa setiap karya sastra yang berbahasa Inggris, dari negara manapun karya sastra itu berasal - selama berbahasa Inggris karya sastra tersebut merupakan karya sastra Inggris. Namun hal ini bukan berarti "Inggris" sebagai sebuah negara, melainkan Inggris dalam hal bahasa.

Walau demikian, berbicara sejarah sastra Inggris tentu tidak terlepas dari bagaimana karya sastra di tanah Britania Raya muncul dan berkembang. Wheeler, dalam Early Periods of Literature memaparkan

${ }^{6}$ Hudson, An Outline History of English Literature., 1. bahwa perkembangan sastra di Barat (Eropa) memiliki pengaruh pada segi intelektual, bahasa, agama, dan seni. ${ }^{7}$ Periode-periode tersebut adalah: Periode Klasik (1200 SM - 455 M), Periode Abad Pertengahan (455 - 1485 M), Renaisans dan Reformasi (1485 - 1660 M), Periode Pencerahan (Neoklasik) (1660-1790 M), Periode Romantis (1790- $1830 \mathrm{M})$, Periode Victoria dan Abad ke-19 (18321901 M), Periode Modern (1914-1945 M), dan Periode Postmodern (1945 M seterusnya)

\section{Periode Modern dalam Sejarah Sastra Inggris}

Berbicara tentang periode modern, tentu ingatan kita langsung diarahkan pada penulis-penulis terkenal seperti: W. B. Yeats, Seamus Heaney, Dylan Thomas, W. H. Auden, Virginia Woolf, dan Wilfred Owen. Karyakarya mereka menjadi representatif dari periode modern di mana tema-tema dari karya sastra yang muncul lebih bebas bila dibandingkan dengan periode sebelumnya. Walaupun demikian, tema "keindahan" yang sering muncul pada periode Victorian mulai menghilang atau ditinggalkan.

Contoh puisi pada masa modern adalah Politics, sebuah puisi yang ditulis oleh William Butler Yeats pada 1939 dan kemudian diterbitkan dalam buku The Collected Works of W.B Yeats ${ }^{8}$. Puisi ini menceritakan tentang interaksi antara dua orang yang sedang berada di tengahtengah Civil War Spanyol dan juga pada masa Pre-War Third Reich Adolf Hitler di Jerman. Interaksi tersebut tergambar pada kutipan puisi berikut: "But $O$ that I were young again/ And held her in my

${ }^{7}$ Wheeler, "Early Periods of Literature". ${ }^{8}$ Yeat, The Collected Works of W.B Yeats: The Poems. 
arms".

Sebagai pensyair yang muncul pada periode modern, Yeath tentu juga memasukkan hal-hal yang sedang terjadi di sekitarnya. Dalam puisi Politics, ia menggambarkan sebuah situasi yang ia rasakan dimana kewaspadaan dan ketakutan akan situasi antar negara Eropa yang sedang bermasalah, terjadi agresi di mana-mana, dan permasalahan politik yang sedang memanas digambarkan 9. Berikut kutipan dari bagian yang dimaksud: "My attention fix/ On Roman or on Russian/ Or on Spanish politics".

Yeath, yang pada awal kemunculannya tidak terlalu diperhitungkan, menjelma menjadi pensyair besar dalam sejarah Britani Raya dan (mungkin pensyair terbesar) dalam sastra Inggris di abad ke-20. Tema, penggambaran, simbol, metafora, dan kepekaan puitisnya mencakup luasnya pengalaman pribadinya, dan juga pengalaman negaranya selama masa-masa pelik. Tema-tema tersebut pada akhirnya menjadi tema umum yang banyak ditulis oleh pensyair-pensyair yang muncul pada periode modern di Eropa khususnya di tanah Britania Raya.

\section{Pengalaman} pribadi, penggambaran kondisi sosial, dan penyuaraan nilai-nilai kemanusiaan yang menjadi cirikhas puisi-puisi Britania Raya juga terjadi di Austalia. Sebut saja Robert Adamson, Kris Hemensley, Bruce Beaver, Vicki Viidikas, Jennifer Maiden dan John A Scott yang merupakan pensyair "baru" di Australia di mana karya-karya mereka banyak menggambarkan tentang simbol-simbol kehidupan.${ }^{10}$ Sebut saja

${ }^{9}$ Maddox, Yeats's Ghosts: The Secret Life of W.B. Yeats.

${ }^{10}$ Lhuede, "The 'New' Australian Poetry: puisi Lunch Date karya Bruce Beaver yang selain menceritakan tentang suasana makan siang, puisi tersebut juga menggambarkan keresahan hati seorang pria tentang dunia yang sedang kacau, banyak kematian di mana-mana, dan bencana alam.

\section{Sejarah Kesusastraan Australia}

Dalam Politics society and the individual, Subhash menjelaskan tentang bagaimana sejarah dari sastra Australia. ${ }^{11}$ Kesusastraan Australia berevolusi seiring dengan datangnya para imigran. Mereka datang dengan membawa berbagai teks, salah satunya adalah teks sastra. Dari jurnal para imigran, kesusastraan Australia berkembang bersamaan dengan perkembangan sosial-politik di negara ini. Pada awalnya, kesusastraan Australia adalah sastra lisan. Saat pertama kali bertemu dengan orang Eropa, orang Aborigin di Australia tidak memiliki bahasa tulisan. "Orang-orang Aborigin dan Torres Strait Islander di Australia telah bercerita sejak dahulu kala." 12

Sebelum drama muncul di Australia, puisi adalah karya sastra pertama yang muncul. ${ }^{13}$ menjelaskan bahwa hanya orang-orang yang berpendidikan di negara asal mereka,

Modernist and Postmodernist Poetics and Twentieth-Century Australian Poetry."

${ }^{11}$ Verma, Politics Society and the Individual: The Dramatic Art of Hannie Rayson., 1.

${ }^{12}$ Toorn, "IIndigenous Texts and Narratives.' The Cambridge Companion to Australian Literature. Ed. Elizabeth Webby.," 19.

${ }^{13}$ Verma, Politics Society and the Individual: The Dramatic Art of Hannie Rayson., 1. 
Inggris, yang bisa membaca atau menulis, hal ini dikarenakan tidak adanya sekolah formal di Australia (pada saat itu). Oleh karena itu, sulit bagi imigran awal untuk mengembangkan keterampilan sastra. Karena penduduk berpendidikan rendah, tidak ada komunikasi tertulis seperti surat kabar.

Puisi awalnya digunakan sebagai luapan emosi narapidana. Melalui puisi, mereka menggambarkan rasa sakit yang mereka rasakan. Saat narapidana merasa sedih, puisi mereka digunakan untuk menunjukkan empati pada penderitaan orang lain. Kurangnya kemampuan menulis atau menulis membuat narapidana mengubah puisi mereka menjadi lagu. Beberapa pensyair yang paling menonjol pada saat itu adalah Michale Massey Robinson, George Barrington dan Francis MacNamara yang juga dikenal sebagai Frank the Poet.

Subhash Verma, seorang akademisi dari Himachal Pradesh University, mengungkapkan bahwa karena isolasi geografisnya dari negaranegara lain di dunia, Australia mendapat kontak dengan negara-negara lain dengan sangat lambat ${ }^{14}$. Selain itu, ia menerangkan bahwa mimpi tentang masa depan Australia dan identitas masyarakatnya mulai digambarkan oleh pensyair Australia abad ke-20. Pensyair terkenal saat itu adalah Bernard O'Dowd, W.C. Wentworth, yang dikenal dengan nama "Australasia, a Ode" (1823), Dorothea Mackellar, Adam Linsay Gordon, Henry Kendall dan Christopher Brennan. Semua menggambarkan Australia, bukan sebagai koloni Inggris namun sebagai negara dengan identitas tersendiri dalam puisinya. ${ }^{15}$

${ }^{14}$ Verma, 3.

${ }^{15}$ Azarias, The Development of English
Pada tahun 1900, pembaca Australia mulai mengembangkan sesuatu untuk ditulis tentang Australia dan tentang diri mereka sendiri 16 Australia telah mulai melihat dirinya sebuah negara, terpisah dari Inggris dan budaya Inggris. Lanskap Australia dijelaskan secara rinci, namun tetap saja masyarakat umum Australia hampir tidak pernah disebutkan.

Ketika Australia menjadi federasi negara-negara merdeka, Henry Lawson, Miles Franklin dan Joseph Furphy membawa transformasi dengan menggambarkan realisme sosial dan identitas nasional dalam novel mereka. ${ }^{17}$ Pemandangan Australia yang luas dan kering menjadi karakter dalam banyak karya fiksi. Tapi masih banyak penulis yang berjuang dengan gagasan tentang apa artinya menjadi orang Australia. Novel petualangan dan asmara menjatuhkan semangat maskulinnya dan berubah menjadi novel nasionalistik. Beberapa novelis mem-promosikan rekonsiliasi dengan masyarakat adat di Australia dan mengembangkan apresiasi yang lebih besar atas hubungan mereka dengan tanah tersebut. Pada tahun 1973, Patrick White menjadi orang Australia pertama yang mendapatkan penghargaan Nobel untuk sastra. Dia menerbitkan dua belas novel, delapan drama, beberapa koleksi cerita pendek Literature. New South Wales: Ulan Press. Australia Government. (n.d). Federation. Australia.Gov.Au.

${ }^{16}$ Webby, Webby, Elizabeth. (2000). Colonial Writers and Readers. The Cambridge Companion to Australian Literature. Ed. Elizabeth Webby. Cambridge: Cambridge University Press. 50-73, 50.

${ }^{17}$ Verma, Politics Society and the Individual: The Dramatic Art of Hannie Rayson., 6. 
dan karya nonfiksi ${ }^{18}$. Fase kontemporer dari novel ini dimulai kira-kira dari tahun 1970. Pada saat ini Australia menyaksikan banyak perubahan politik, sosial dan ekonomi dan akibatnya fiksi mencapai tinggi, yang belum pernah dialami sebelumnya.

Dewasa ini, di Australia novel mencerminkan keragaman budaya masyarakat kontemporer. 19 Seperti yang dikatakan oleh 20 bahwa kini masyarakat multikultural tidak memiliki tujuan yang kompleks. Selain itu, novel tidak lagi menjadi bagian dari ikatan budaya masyarakat. Mereka sekarang dipasarkan ke konsumen yang sama.

\section{Periode Modern dan Penulis- Penulis Australia}

Australia memiliki sejarah di mana 160.000 pria dan wanita, yang berasal dari Inggris, datang dengan kapal yang berlabuh di Sydney pada tahun 1788 hingga $1868^{21}$. Proses pengiriman imigran asal Inggris tersebut juga dibarengi dengan ditemukannya tambang emas di negara tersebut. Hal ini mengakibatkan Australia dieksploitasi kekayaannya. Bahkan, tidak hanya oleh Inggris, imigran lain dari beragai negara juga datang untuk menikmati kekayaan tersebut.

Hingga akhirnya, masyarakat Australia berusaha untuk memperjuangkan kemerdekaan mereka yang berbuah pada pengizinan enam koloni Australia oleh pemerintah Inggris untuk ${ }^{18}$ Verma, 6.

${ }^{19}$ Verma, 7.

${ }^{20}$ Lever, Fiction: Innovation and Ideology. The Oxford Literary History of Australia. Eds. Bruce Bennett and Jennifer Strauss., 330.

${ }^{21}$ Taufik, "Asal-Usul Australia, Para Bandit Inggris Yang Terbuang.”, memerintah dengan hak mereka sendiri sebagai bagian dari persemakmuran Australia. Dengan kata lain, pada tanggal 1 Januari 1901 Inggris "memberikan" kemerdekaan kepada Australia dan membentuk sebuah negara yang berbentuk monarki konstitusionaldisebut 'monarki konstitusional' karena Persemakmuran Australia didirikan dengan sebuah konstitusi tertulis kepala negara Australia adalah Ratu Victoria.

Melalui sejarah tersebut, tentu sedikit banyak perkembangan Australia di berbagai segi kehidupan mendapat pengaruh dari Inggris. Terlebih orangorang yang "dipindahkan" ke Australia pada saat itu adalah orang-orang yang lahir dan tumbuh di Inggris. Terutama untuk perkembangan kesusastraan di Australia, khususnya pada era modern yang berlangsung pada tahun 1914-1945 jika merujuk pada skema Early Periods of Literature yang ditulis oleh ${ }^{22}$.

Pada periode modern, muncul beberapa nama pensyair di Australia yang memiliki ketertarikan kuat pada sejarah seni Eropa, seni visual secara lebih luas, perpaduan kisah cinta sentimental, isu perang dunia pertama, dan idiom naratif. Dari sekian banyak pensyair, peneliti mengambil sample seorang penulis asal Australia yang karya-karyanya dapat dikatakan sebagai puisi yang merepresentasikan tema-tema yang berkembang di periode modern Australia. Mereka adalah C. J. Dennis. Pensyair tersebut masuk dalam periode modern di Australia yang masingmasing aktif menulis dan menerbitkan puisi mereka pada tahun 1910 dan 1930 .

\section{Sejarah Pensyair Australia}

Wheeler menjelaskan bahwa

22 Wheeler, " Early Periods of


puisi Australia mulai menemui perkembangannya pada saat periode kolonial (penjajahan). Salah satunya adalah balada yang diciptakan oleh narapidana. ${ }^{23}$ Balada, yang disusun oleh narapidana kulit putih,menyebabkan komunitas narapidana yang mencurahkan pemikiran dan perasaannya melalui sistem pemasyarakatan, mengutukkehidupankeras dipenjarakan, atau nostalgia dan pujian bagi mereka yang melarikan diri dari tempat tersebut. Dua balada paling populer yang masih beredar adalah Bold Jack Donahue dan The Wild Colonial Boy.

Berbicara tentang sejarah pensyair Australia, tentu yang terbayang adalah sosok pensyair Charles Harpur (1813-1865) yang dikenal sebagai 'father of Australian poetry'. Ia merupakan pensyair yang tidak hanya mencerminkan realitas sosial, tapi juga yang pertama mengembangkan seni puisinya tentang rasa memiliki dengan Australia. ${ }^{24}$ Dialah yang mengumumkan 'identitas' dan 'realitas' dalam bahasa Inggris dengan sangat bangga. Anehnya, ia lahir dari orang tua yang menjadi narapidana, dibawa ke Australia. Di sisi lain Charles Harpur "took the vocation of poetry" dengan sungguh-sungguh dan sangat mencintai negaranya, Australia.

Harpur masih mencoba untuk mewujudkannya dalam karyanya, "The Australians' reach for identity within the framework of a transplanted culture" (Australian Literature dalam Bloke). ${ }^{25}$ Alam adalah tema dominan Harpur, The Bush Fire adalah contoh untuk deskripsi

${ }^{23}$ Sreedharan, A D Hope s Poetry: An Expression of Something Autonomous And Beautiful in Itself., 6.

${ }^{24}$ Sreedharan, 7.

${ }^{25}$ The Sentimental Bloke, "The Advertiser. Adelaide: National Library of Australia.," 9. lokal yang tertulis dalam puisinya. Dalam puisi lain yang terkenal, dia telah menyuarakan ketenangan dan keluasan alam Australia melalui $A$ Midsummer Noon in the Australian Forest. Sedangkan karyannya yang lain, The Greek of the Four Graves, menggambarkan pemukim yang dibunuh oleh suku Aborigin.

Melalui mereka, terutama Harpur, puisi-puisi Australia yang lahir jadi terasa memiliki aroma 'Romantis'. Namun, tetap bahwa imajinasi Harpurlah yang secara khusus diburu untuk memberi inspirasi, dan dalam The Dream by Fountain, dia bernyanyi untuk Muse dan puisi Australia:

I am the Muse of the Evergreen Forest

I am the spouse of thy spirit, lone Bard!

Even in the days when thy boyhood there worst

Thy pastimes drew on thee my dearest regard.

(Australian Literature dalam Sheedharan). ${ }^{26}$

Namun, bagaimana dengan era modern Australia? Seperti yang sudah disebutkan pada subchapter sebelumnya, periode sastra Australia terpengaruh dengan bagaimana periode sastra berjalan di negeri ratu Elizabeth. Banyak hal yang melatar belakanginya, salah satunya adalah kedatangan imigran dalam jumlah masive, yang juga sudah disinggung sebelumnya.

Tentu banyak pensyair yang

${ }^{26}$ Sreedharan, A D Hope s Poetry : An Expression of Something Autonomous And Beautiful in Itself., 10. 
tergabung dalam pembabakan pensyair periode modern Australia. Namun, dalam paper ini, peneliti akan fokus pada satu pensyair yang memiliki hal menarik dalam penulisannya, yakni Clarence Michael James Dennis.

\section{Clarence Michael James Dennis}

C.J Dennis (Clarence Michael James Dennis) merupakan anak pertama dari James Dennis, seorang pengusaha hotel, dan istrinya Kate (née Tobin), lahir pada tanggal 7 September 1876 di Auburn di Clare Valley, Australia Selatan. Pada usia 17 tahun, Dennis harus berhenti sekolah dan bekerja sebagai pegawai di Adelaide sebelum kembali ke rumah ayahnya di Laura, di Flinders Ranges. Pada akhir 1890-an, Dennis bekerja pada sebuah surat kabar di kota Adelaide, The Critic, sebagai jurnalis. Namun, pekerjaan tersebuthanya bertahan selama satu tahun sebelum ia kembali bekerja bersama ayahnya untuk mengurus hotel.

Di samping itu, Dennis juga sempat mendirikan sura kabar mingguan pro-nasionalis The Gadfly. Namun usaha tersebut gagal dan akhir 1907 Dennis meninggalkan koran tersebut dan pergi ke Victoria. Dia pergi untuk tinggal di sebuah gubuk di permukiman Toolangi yang terisolasi, di tepi Lembah Yarra. Di sini Dennis bisa berkonsentrasi untuk menulis, hingga akhirnya awal 1913 ia menerbitkan buku puisi pertamanya.

Setelah itu, Karir Dennis bisa dibilang cukup melejit. Setelah buku kumpulan puisi pertamanya terbit, ia kemudian menerbitkan karya-karya selanjutnya dalam bentuk kumpulan puisi, satir, dan novel. Tiga tahun berselang setelah menerbitkan karyanya di tahun 1935, Dennis menghembuskan nafas terakhirnya setelah mengalami gagal jantung yang disebabkan oleh asma pada tanggal 22 Juni 1938. Dikutip dari The Australian Library ${ }^{27}$, terlampir di bagian akhir karya-karya C.J Dennis yang terbit dalam kurun waktu 27 tahun.

\section{The Songs of a Sentimental Bloke, Karya Fenomenal C.J Dennis}

\section{The Songs of a Sentimental} Bloke (1916) adalah verse novels (prosa lirik) pertama dari C.J Dennis. Karya ini pertama kali diterbitkan pada tahun 1915 oleh salah satu penerbit di Sydney: Angus \& Robertson. Karya yang mendapatkan kata pengantar dari Henry Lawson ini dalam beberapa tahun diterbitkan dalam beberapa Edisi, diantaranya: Edisi Pocket (1916), edisi Amerika berjudul Doreen and the Sentimental Bloke diterbitkan pada tahun yang sama.

Sebuah portal berita, The Australian, memuat sebuah laporan bahwa The Songs of a Sentimental Bloke telah terjual lebih dari 51.000 eksemplar dalam tiga bulan (Thompson, 2013). Hal ini juga mempengaruhi Angus \& Robertson sebagai penerbit yang kemudian mendapatkan untung yang berlimpah dari penjualan karya C.J Dennis itu. Dalam kumpulan puisi tersebut, terdapat empat belas karya Dennis yang dibukukan: A Spring Song, The Intro, The Stoush O' Day, Doreen,

${ }^{27}$ The Australian Library merupakan prakarsa bersama dari University of Sydney dan the Copyright Agency Limited (CAL). Dimulai pada tahun 2004 dengan situs prototipe yang dikembangkan oleh pensyair terkemuka John Tranter, proyek ini didanai oleh major Linkage Grant dari Australian Research Council (ARC), CAL dan University of Sydney Library. Sebuah tim peneliti dari University of Sydney, yang dipimpin oleh Profesor Elizabeth Webby dan John Tranter, yang bekerja sama dengan CAL, telah mengembangkan Australian Poetry Library sebagai arsip internet permanen dari sumbersumber puisi Australia. 
The Play, The Stror 'At Coot, The Siren, Mar, Pilot Cove, Hitched, Beef Tea, Uncle Jim, The Kid, dan The Mooch O' Life.

Dalam garis besar cerita, karya C.J Dennis ini menceritakan sebuah percintaan Bloke dan Doreen yang dibumbui dengan drama penolakan, permasalahan cinta, dan lain sebagainya. dalam penulisannya, Dennis memberikan banyak ungkapanungkapan yang begitu menawan. Selain itu, ungkapan, umpatan, dan perkataan yang menggunakan Australian Slang Language juga sering (atau bahkan selalu) digunakan. contohnya adalah: "Spare me bloomin' days" dan "You could 'er knocked me down wiv 'arf a brick!"” 28.

The world 'as got me snouted jist a treat;

Crool Forchin's dirty left 'as smote me soul;

An' all them joys o' life I 'eld so sweet

Is up the pole.

Fer, as the poit sez, me 'eart 'as got

The pip wiv yearnin' fer - I dunno wot.

Dikutip dari bagian A Spring Song 29

Dalam kutipan bait di atas, yang terdapat pada A Spring Song, diperlihatkan bahwa penggambaran suasana yang dilakukan oleh C.J Dennis memiliki ciri khas begitu ekspresif. Pengandaian dalam bagian "Crool

\footnotetext{
${ }^{28}$ Dennis, The Songs of a Sentimental Bloke. Sydney, Angus \& Robertson Ltd., 22-27.

${ }^{29}$ Dennis, 15-20.
}

Forchin's dirtyleft 'as smoteme soul'juga menggambarkan bagaimana pengaruh era victorian, yaitu aesteticism - seperti meningkatkan moral masyarakat dan menekankan isu-isu sosial, ilmiah, dan keagamaan-yang masih terbawa pada karya C.J Dennis ini. Hal ini tentu lumrah dan banyak terjadi pada karyakarya awal periode Modern yang belum terlalu jauh meninggalkan periode sebeumnya.

\section{Karya C.J Dennis Era Perang Dunia I}

The Moods of Ginger Mick merupakan karya Dennis yang dapat dikatakan cukup sukses pada masa Perang Dunia 1. Hal ini berdasarkan jumlah penjualan tersebut yang mencapai 70.000 eksemplar di tahun pertamanya (The Advertiser, 1918). Dalam teknik penulisannya, Dennis menggunakan bait dengan sajak teratur seperti ababcc dan lain sebagainya. Penggambaran tersebut terlihat pada contoh bait yang dikutip di bawah ini:

a) Contoh bait dengan sajak ababcc dalam The Moods of Ginger Mick:

NOW, when a bloke 'e cracks a bloke fer insults to a skirt,

An' wrecks a joint to square a lady's name,

They used to call it chivalry, but now they calls it dirt,

An' the end of it is cops an' quod an'shame.

Ferinsults to fair Gwendoline they 'ad to be wiped out;

But Rosie's sort is jist fair game-when Ginger ain't about. 


\section{Dikutip dari Puisi Duck an' Fowl $^{30}$}

b) Contoh bait dengan sajak ababcc dalam The Moods of Ginger Mick:

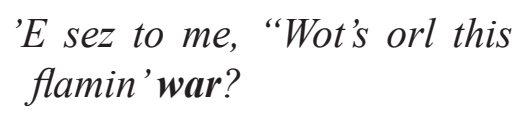

The papers torks uv nothin' else but scraps.

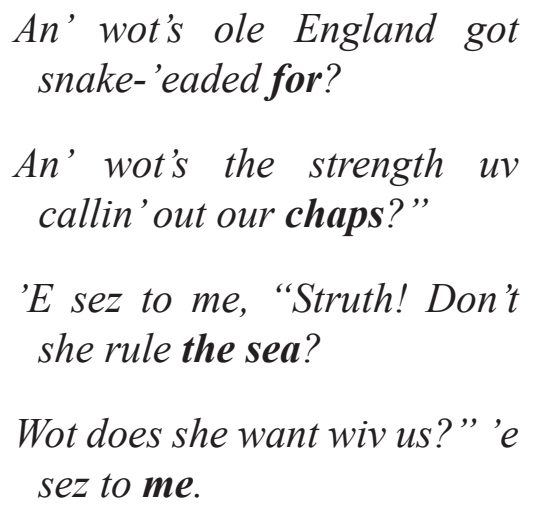

\section{Dikutip dari Puisi War $^{31}$}

Pemilihan diksi tersebut tentu bukan merupakan hal yang hanya memikirkan keselerasan bunyi dalam puisi. Namun juga memiliki makna bila dikaitkan dengan konten yang diangkat. Bila diperhatikan lebih dalam, keteraturan rhyme dalam puisi-puisi di atas juga memiliki hubungan dengan konten dan pesan yang disampaikan oleh pensyair. Dari bait pertama yang dikutip, C.J Dennis menyampaikan bagaimana seorang pria yang tampak seperti pahlawan dengan menyelamatkan kehidupan seorang wanita, kendati demikian ia dan jasa-jasanya dilupakan.

Puisi-puisi C.J Dennis dalam The Moods of Ginger Mick tidak hanya memiliki bahasa yang mampu mengguhah rasa, namun juga memiliki imajinasi dan rangkaian materi cerita

\footnotetext{
${ }^{30}$ Dennis, The Moods of Ginger Mick. Montana: Kessinger Publishing., 15-16.

${ }^{31}$ Dennis, 23-26.
}

yang menarik. Ia menggambarkan sebuah suasana yang digambarkan begitu natural untuk mengangkat isu atau tema sebenarnya. Seperti halnya tema perang yang ia angkat dalam puisinya yang berjudul War. Dalam puisi tersebut, ia menceritakan pengalaman Australia ketika terlibat dalam perang dunia pertama. Pengalaman tersebut dituliskan dalam sudut pandang tentaratentara yang bertugas di medan perang. Kutipan mengenai suasana perang berada pada kutipan berikut:

$$
\begin{aligned}
& \text { An' as the soljer fades acrost } \\
& \text { the street, } \\
& \text { Mick strikes a light an' sits } \\
& \text { down on 'is truck, } \\
& \text { An' chews 'is fag - a sign 'is } \\
& \text { nerve is beat- } \\
& \text { An' swears a bit, an' sez 'e's } \\
& \text { done 'is luck. } \\
& \text { 'E grouches there ten minutes, } \\
& \text { maybe more, }
\end{aligned}
$$

Then sez quite sudden, "Blarst the flamin'war!"

\section{Dikutip dari Puisi War $^{32}$}

Walaupun demikian, puisi tersebut juga memiliki sudut pandang lain dari seorang tentara. Parbincangan antara prajurit yang mengungkapkan kekesalan mereka terhadap rival mereka yang melakukan kekejaman dan kebengisan terhadap perempuan dan anak-anak. Hal tersebut tergambar pada bait berikut:

I tells 'im wot I read about the 'Uns,

\footnotetext{
An' wot they done in Beljum an' in France,

32 Dennis, 23-26.
} 
Wiv drivin' Janes an' kids before their guns,

An' never givin' blokes a stray dawg's chance;

An' 'ow they think they've got the whole world beat.

Sez 'e, "I'll crack the first Dutch cow I meet!"

\section{Dikutip dari Puisi War $^{33}$}

Perang dunia pertama, yang melibatkan Australia, memberikan efek kepada Dennis pada proses penulisan karya-karya selanjutnya disamping The Moods of Ginger Mick. Koleksi puisi Digger Smith yang ditulis oleh C.J. Dennis pada tahun 1918 merupakan koleksi puisi sejenis yang ditulis satu bulan sebelum perang dunia pertama berakhir. Yang membedakan adalah Digger Smith lebih mengangkat cerita romantic verse-story dari 'the Bloke' soldier mate. Dua contoh puisi dari Digger Smith yang mengangkat tema tersebut adalah cerita antara Jim dan kekasihnya yang masing-masing dituliskan dalam dua puisi yang berbeda dengan judul Uncle Jim dan Jim's Girl.

\section{Karya C.J Dennis Pasca-Perang Dunia 1}

Karya sastra merupakan sebuah sarana yang dapat memberikan sebuah gambaran kehidupan dan juga memberikan gambaran tentang kenyataan sosial yang terkadang sianggap sebagai sebuah tiduran dari alam dan dunia subjektif manusia 34 Kejadian atau momen-momen penting dalam hidup seorang pengarang sedikit banyak pasti akan mempengaruhi proses kreatif dari seorang penulis

${ }^{33}$ Dennis, 23-26.

${ }^{34}$ Wellek and Austin, Teori Kesusastraan., 98. dalam menghasilkan karyanya. Dalam pembahasan ini, tentu menarik bila mencermati bagaimana C.J Dennis, selain mengalami masa sebelum perang dan masa perang, ia juga merasakan dan berkarya pada masa di mana perang telah selesai.

Beberapa karya-karya C.J Dennis yang lahir setelah Perang dunia pertama adalah: Jim of the Hills: A Story in Rhyme, A Book for Kids, Rose of Spadgers: A Sequel to "Ginger Mick", dan The Singing Garden. Yang paling menarik untuk dibahas pada paper ini, sebagai representasi dari karya Dennis pasca perang adalah The Singing Garden.

The Singing Garden (1935) merupakan kumpulan puisi dan prosa C.J Dennis yang diterbitkan dua puluh tahun setelah perang dunia pertama berakhir. Sebelum membahas isinya, hal yang paling berbeda dari karya C.J Dennis sebelumnya yang telah dibahas di atas adalah penggunaan bahasa. Penggunaan bahasa dalam karya kali ini jauh dari penggunaan Australian Slang Language. Contohnya adalah pada kutipan bait sebagai berikut:

The kindly offices of night are done.

A grey thrush carols forth his morning hymn,

Then proud, triumphant of a new day won,

The magpie's trumpet tops a lofty limb.

By the pool's mirrored brim

The drowsing daisies open one by one: 
"Wake, brothers, wake! Here comes our lord, the Sun!

\section{Look up and worship him!”}

Dikutip dari puisi Dawn ${ }^{35}$

\section{The Singing Garden} terbagi menjadi empat chapter: spring, summer, autumn, dan winter. Penggambaran suasana setiap musim digambarkan dengan begitu indah oleh Dennis. Pemilihan diksinya ketika menggambarkan beberapa situasi pada setiap musimnya membawa para pembaca pada imajinasi tentang bagaimana kejadian yang sedang berlangsung. Salah satunya adalah penggamaran pergantian musim menuju Summber dan penggunaan indera dimaksimalkan dalam setiap baitnya. Hal tersebut tergambar pada kutipan bait berikut:

\section{Now comes the blossoming. At Beauty's birth
Promise is brought to proud accomplishment,
And all things hymn the glory of the earth
In this great symphony so subtly blent \\ Of sight and sound and scent, \\ Weaving with all a note of carefree mirth,}

Singing of sudden riches, boundless worth,

Now to be freely spent.

\footnotetext{
${ }^{35}$ Dennis, (1935). The Singing Garden. Sydney: Angus \& Robertson. Retrieved from: Http:// $W w w$.Australianculture.Org/the-SingingGarden-c-j-Dennis/, 3-4.
}

\section{Dikutip dari puisi Summer ${ }^{36}$}

C.J Dennis menulis sebuah tema yang sama sekali berbeda dengan apa yang pernah ia tulis ketika tahun-tahun perang sedang berlangsung. Pada The Singing Garden, kehidupan manusia dengan intrik percintaan dan kedamaian alam digambarkan. Selain pada contoh kutipan bait di atas, terdapat pula bagian di mana penggambaran metafora suguhkan seperti " A soft cloud's tattered fleece drifts idly where". Unsur-unsur seperti ini sebelumnya jarang sekali diangkat pada puisi-puisi lamanya. Hal tersebut terdapat pada kutipan berikut ini:

\section{From the deep forest, on the clean} crisp air,

The bushman's axe-blows echo sharply clear;

\section{A soft cloud's tattered fleece drifts} idly where

Glows azure hope. Impatient to appear,

Springs now full many a spear

Of marching daffodils. Shorn of cold care,

The joyous bush birds vie with flutings rare.

Spring surely must be near.

Dikutip dari puisi Promise of Spring ${ }^{37}$

Secara garis besar, perbedaan atau perubahan yang terjadi pada penulisan karya-karya C.J Dennis yang pra- hingga pasca-perang dunia pertama adalah pada tema yang diangkat. Kehidupan tentara sering

\footnotetext{
${ }^{36}$ Dennis, 55-56.

${ }^{37}$ Dennis, $181-82$.
} 
diangkat ketika masa-masa perang itu terjadi. Di sisi yang lain, pasca-perang dunia pertama membawa Dennis menjadi sosok pensyair yang memiliki ketertarikan tema kehidupan percintaan yang diwarnai dengan bagaimana penggambaran dunia beserta alamnya yang begitu indah. Dalam hal ini, dapat disimpulkan bahwa gambaran alam atau sosial benar-benar berpengaruh pada penulisan karya dari C.J Dennis.

\section{Penutup}

Clarence Michael James Dennis merupakan seorang pensyair dan penulis prosa yang memiliki kegigihan yang begitu tinggi. Sempat gagal dan diremehkan, karya-karyanya kemudian muncul sebagai salah satu yang terbaik di Australia. Isu-isu tentang kemanusiaan yang di sampaikan dalam penggambaran perang, percintaan, dan lain sebagainya menjadi sebuah hal menarik dari puisipuisi C.J. Dennis.

Selanjutnya, karya-karya C.J Dennis sejatinya, di awal kemunculannya sebagai pensyair, masih terpengaruh dengan bagaimana cirikhas puisi di era victorian. Isu-isu seperti moral masyarakat, sosial, ilmiah, dan keagamaan ia angkat dalam karyanya, salah satunya adalah yang berjudul A Spring Song yang di bahas dalam penelitian ini.

Puisi-puisi C.J Dennis secara umum mengangkat tema-tema yang dapat dipahami dan dirasakan oleh masyarakat di seluruh dunia. Bagaimana perang berlangsung, kehidupan tentara yang sedang melaksanakan tugasnya, hingga sisi lain dari tentara diangkat oleh Dennis. Hal tersebut tentu sejalan dengan apa yang terjadi pada masa ia menulis karya tersebut. Hal ini pula yang mengamini pendapat bahwa karya sastra adalah sebuah cerminan dari sebuah masa.

Kemanusiaan yang menjadi nilai dalam karya-karyanya juga tetap disampaikan oleh C.J Dennis pada pasca perang. Namun, ia membalut nilai tersebut dengan penggambaran yang berbeda. Ia menggunakan suasana lain, seperti percintaan, kehidupan seharihari, untuk tujuan yang sama. Hal ini yang membuat C.J Dennis dan karyanya tetap selalu mendapatkan tempat di penikmat sastra sepanjang karirnya.

\section{Daftar Pustaka :}

Azarias, Brother. The Development of English Literature. New South Wales: Ulan Press. Australia Government. (n.d). Federation. Australia.Gov.Au. New South Wales: Ulan Press Australian Government. n.d) Federation Australia.gov.au(, 1879. http:// www.australia.gov.au/aboutgovernment/how-governmentworks/federation.

Damono, Sapardi Djoko. Bilang Begini Maksudnya Begitu. Jakarta: Gramedia Pustaka Utama, 2017.

Dennis, C.J. (1935). The Singing Garden. Sydney: Angus \& Robertson. Retrieved from: Http://Www. Australianculture.Org/theSinging-Garden-c-j-Dennis/, 1935. Retrieved from: http:// www.australianculture.org/thesinging-garden-c-j-dennis/.

. The Moods of Ginger Mick. Montana: Kessinger Publishing., 1916. http://www.telelib. com/ 
authors /D/DennisCJ/ verse/ gingermick/ index.htm.

The Songs of a Sentimental Bloke. Sydney, Angus \& Robertson Ltd., 1917. Retrieved from http://www. australianculture.org/the-songsof-a-sentimental-bloke/.

Hudson, William Henry. An Outline History of English Literature. London: G. Bell and Sons, LTD, 1913.

Lever, Susan. Fiction: Innovation and Ideology. The Oxford Literary History of Australia. Eds. Bruce Bennett and Jennifer Strauss. Melbourne: Oxford University Press, 1998.

Lhuede, Elizabeth Maire. "The 'New' Australian Poetry: Modernist and Postmodernist Poetics and Twentieth-Century Australian Poetry." Sydney: Macquarie University, 1994. http:// hdl. handle. net/1959. 14/205698.).

Maddox, Brenda. Yeats's Ghosts: The Secret Life of W.B. Yeats. London: Haper Perennial, 1999.

Sreedharan, Amodini. A D Hope $s$ Poetry: An Expression of Something Autonomous And Beautiful in Itself. Aligarh: Aligarh Muslim University, 2006.

Taufik, Muhammad. "Asal-Usul Australia, Para Bandit Inggris Yang Terbuang."." Jakarta:
Merdeka.Com, 2013. https:// www .merdeka. com/peristiwa/ asal-usul-australia-para-banditinggris-yang-terbuang.html.

The Sentimental Bloke. "The Advertiser. Adelaide: National Library of Australia.," April 10, 1918, 7.

Toorn, Penny Van. "Indigenous Texts and Narratives.' The Cambridge Companion to Australian Literature. Ed. Elizabeth Webby." Cambridge : Cambridge University Press, 2000, pp 19-49.

Verma, Subhash. Politics Society and the Individual: The Dramatic Art of Hannie Rayson. Summer-Hill: Himachal Pradesh University, 2014.

Webby, Elizabeth. Webby, Elizabeth. (2000). Colonial Writers and Readers. The Cambridge Companion to Australian Literature. Ed. Elizabeth Webby. Cambridge: Cambridge University Press. 50-73. Cambridge: Cambridge University Press, 2000.

Wellek, Rene, and Warren Austin. Teori Kesusastraan. Jakarta: Gramedia Pustaka Utama, 2014.

Wheeler, L.K. " Early Periods of Literature”, 2010. Retrieved from web.cn.edu/kwheeler/ documents/Periods_Lit_History. pdf.

Yeat, William Butler. The Collected 
Works of W.B Yeats: The Poems. Second edition. Vol. Volume I. New York: Scribner, 1996.

Yudiono, K.S. Pengantar Sejarah Sastra Indonesia. Jakarta: Grasindo, 2010 .

\section{Lampiran}

\section{Tabel 1. Daftar Karya C.J Dennis}




\begin{tabular}{|c|c|c|c|c|}
\hline No. & Judul & $\begin{array}{l}\text { Tahun } \\
\text { Terbit }\end{array}$ & $\begin{array}{l}\text { Kota dan } \\
\text { Penerbit }\end{array}$ & Jenis \\
\hline 1 & $\begin{array}{l}\text { Backblock } \\
\text { Ballads and } \\
\text { Other Verses }\end{array}$ & 1913 & $\begin{array}{l}\text { Melbourne: E. } \\
\text { W. Cole }\end{array}$ & Kumpulan Puisi \\
\hline 2 & $\begin{array}{l}\text { The Songs of } \\
\text { a Sentimental } \\
\text { Bloke }\end{array}$ & 1916 & $\begin{array}{l}\text { Sydney: Angus } \\
\text { and Robertson }\end{array}$ & Kumpulan Puisi \\
\hline 3 & $\begin{array}{l}\text { The Moods of } \\
\text { Ginger Mick }\end{array}$ & 1916 & $\begin{array}{l}\text { Sydney: Angus } \\
\text { and Robertson }\end{array}$ & Kumpulan Puisi \\
\hline 4 & $\begin{array}{c}\text { The Glugs of } \\
\text { Gosh }\end{array}$ & 1917 & $\begin{array}{l}\text { Sydney: Angus } \\
\text { and Robertson }\end{array}$ & Satir \\
\hline 5 & Doreen & 1917 & $\begin{array}{l}\text { Sydney: Angus } \\
\text { and Robertson }\end{array}$ & buklet dari empat puisi \\
\hline 6 & Digger Smith & 1918 & $\begin{array}{l}\text { Sydney: Angus } \\
\text { and Robertson }\end{array}$ & Kumpulan Puisi \\
\hline 7 & $\begin{array}{l}\text { Jim of the } \\
\text { Hills: A Story } \\
\text { in Rhyme }\end{array}$ & 1919 & $\begin{array}{l}\text { Sydney: Angus } \\
\text { and Robertson }\end{array}$ & Novel \\
\hline 8 & A Book for Kids & 1921 & $\begin{array}{l}\text { Sydney: Angus } \\
\text { and Robertson }\end{array}$ & Puisi \\
\hline 9 & $\begin{array}{c}\text { Rose of } \\
\text { Spadgers: } \\
\text { A Sequel to } \\
\text { "Ginger Mick", }\end{array}$ & 1924 & $\begin{array}{c}\text { Sydney: } \\
\text { Cornstalk } \\
\text { Publishing }\end{array}$ & Puisi \\
\hline 10 & $\begin{array}{c}\text { The Singing } \\
\text { Garden }\end{array}$ & 1935 & $\begin{array}{l}\text { Sydney: Angus } \\
\text { and Robertson }\end{array}$ & Puisi \\
\hline
\end{tabular}

